\title{
Penumbuhan dan Pengembangan Wirausaha Baru pada Era Digital Bagi Generasi Muda di Kelurahan Agrowisata Kecamatan Rumbai Kota Pekanbaru Provinsi Riau
}

\author{
Machasin, Taufiqurrahman, Dewita Suryati Ningsih, Ezky Tiyasiningsih' \\ Mida Aprilina Tarigan, Arika Fitriani
}

Dosen Fakultas Ekonomi dan Bisnis Universitas Riau, Pekanbaru, Riau, Indonesia

\begin{abstract}
The role of universities in motivating their undergraduate graduates to become a young entrepreneur is very important in growing the number of new entrepreneurs. With the increase in youth entrepreneurship will reduce the increase in the number of unemployed even increase the number of jobs. Pekanbaru City is an area with abundant natural resource potential. For this reason the phenomenon of unemployment among young people, apart from being caused by limited employment, is also due to the synchronization of graduates' qualifications with the needs of the labor market / business (link and match).

However, this also explains the low level of entrepreneurship that can be generated from the world of education. To that end, efforts to develop entrepreneurship, especially at the age of youth through training and community service activities must continue to be encouraged. This effort needs to be done as an effort to create young and strong young entrepreneurs. Based on this, a community service program was designed with the title "Growth and Development of New Entrepreneurs in the Digital Era for Young Generation in Agrowisata Village, Rumbai District, Pekanbaru City, Riau Province
\end{abstract}

Keyword: New Enterppreneurs, Digital Era, Agrowisata Village

Email Address : machasin@gmail.com

\section{Pendahuluan}

Enterpreneur merupakan salah satu dimensi penting dalam membentuk jiwa pemuda Indonesia, disamping jiwa kepemimpinan dan kepeloporan sebagaimana termuat dalam Tujuan Pembangunan Kepemudaan pasal 3, UndangUndang (UU) No.40 Tahun 2009. Kewirausahaan pemuda perlu dikembangkan untuk mendorong kemandirian pemuda dibidang ekonomi, mengingat tingkat pengangguran di Indonesia saat ini masih cukup tinggi. Berdasarkan data BPS, Angkatan kerja Indonesia pada Agustus 2018 sebanyak 131,01 juta orang, dan yang bekerja sebanyak 124,01 juta orang. Tingkat Pengangguran Terbuka (TPT) Agustus 2018 sebesar 5,34 persen. Maka, gerakan pemberdayaan masyarakat yang dilakukan oleh individu, perusahaan atau lembaga merupakan salah satu upaya untuk mencari solusi masalah tersebut.

Persoalan rendahnya minat dan pemuda saat ini menjadi pemikiran serius banyak pihak, baik pemerintah, dunia pendidikan, dunia industri, maupun masyarakat. Seharusnya pada saat masa muda harus ditanamkan jiwa enterpreneur yaitu jiwa berani berusaha mendapatkan ide dan melakukan tindakan yang akan menghasilkan nilai ekonomis tapi itu sangat jarang sekali ditemukan pada pemuda-pemuda masa kini, hal tersebut bisa disebabkan tidak tahu harus mulai dari mana dan dimana tempat atau wadah untuk mengemukakan ide-ide tersebut.

Peranan perguruan tinggi dalam memotivasi lulusan sarjananya menjadi seorang enterpreneur muda sangat penting dalam menumbuhkan jumlah entrepreneur baru. Dengan meningkatnya entrepreneur dari kalangan pemuda akan 
mengurangi pertambahan jumlah pengangguran bahkan menambah jumlah lapangan pekerjaan.

Kota Pekanbaru merupakan Kota dengan kontribusi PDRB tanpa migas terbesar dan 3 terbesar dengan migas terhadap PDRB Provinsi
Riau. Data dari Badan Pusat Statistik menunjukkan trand laju pertumbuhan ekonomi dengan migas Kota Pekanbaru mengalami fluktuasi selam 4 tahun terakhir.

\section{Grafik 1}

Pertumbuhan Ekonomi Kota Pekanbaru Periode 2014-2017

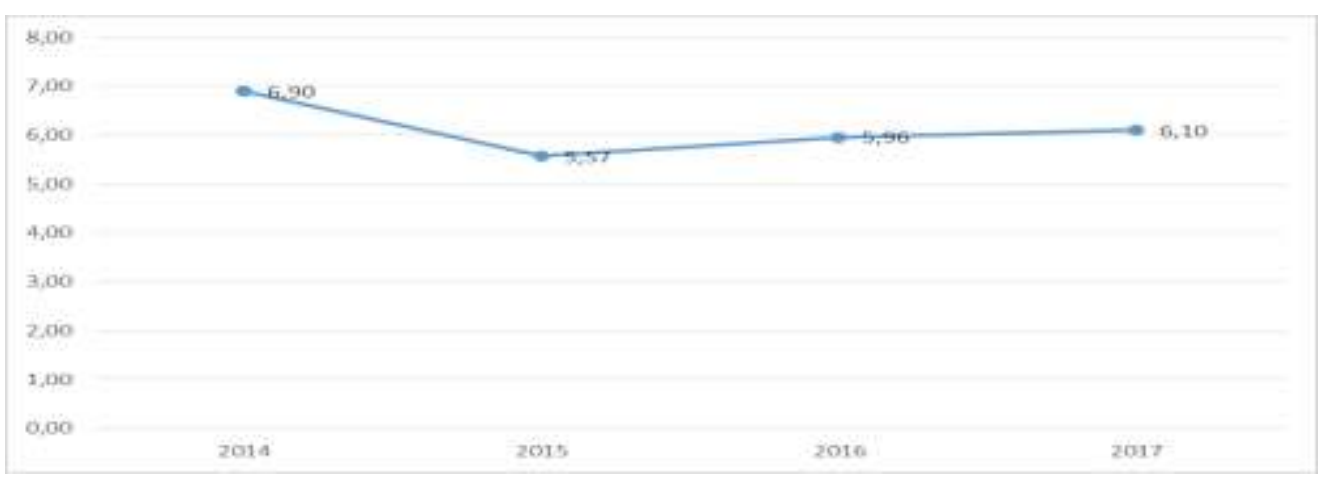

Sumber: BPS Kabupaten Pekanbaru

Besarnya kontrribusi PDRB baik dengan migas maupun tanpa migas terhadap PDRB Provinsi dan trand pertumbuhan ekonomi yang terus mengalami peningkatan tentu tidak terlepas dari peran sektor UMKM sebagai sektor penggerak perekonomian daerah. Data dari Badan Pusat Statistik Provinsi Riau menunjukkan jumlah UMKM tertinggi di Provinsi Riau.

Tabel 1

Jumlah UMKM Provinsi Riau

\begin{tabular}{|l|c|c|}
\hline Kabupaten & Jumlah & Presentase (\%) \\
\hline Kuantan Singingi & 30.353 & 5,96 \\
\hline ndiragiri Hulu & 36.316 & 7,13 \\
\hline ndragiri Hilir & 44.654 & 8,77 \\
\hline Pelalawan & 28.145 & 5,53 \\
\hline Siak & 32.740 & 6,43 \\
\hline Kampar & 68.731 & 13,5 \\
\hline Rokan hulu & 41.330 & 8,12 \\
\hline Bengkalis & 43.253 & 8,49 \\
\hline Rokan Hilir & 43.152 & 8,47 \\
\hline Kepulauan Meranti & 15.051 & 2,96 \\
\hline Pekanbaru & 99.175 & 19,47 \\
\hline Pumai & 26.361 & 5,18 \\
\hline Total & 509.252 & 100 \\
\hline
\end{tabular}

Sumber : Badan Pusat Statistik, 2018

Besarnya jumlah UMKM juga diikuti oleh besarnya pengangguran dikalangan terdidik di Kota Pekanbaru. Untuk itu fenomena pengangguran di kalangan pemuda, selain disebabkan karena terbatasnya lapangan pekerjaan, juga disebabkan karena tidak 
sinkronnya kualifikasi lulusan dengan kebutuhan pasar tenaga kerja/usaha (link and match). Namun, hal tersebut juga sekaligus menjelaskan masih rendahnya tingkat kewirausahaan yang dapat dihasilkan dari dunia pendidikan. Untuk itu, upaya pengembangan kewirausahaan khususnya di usia pemuda melalui kegiatan pengabdian masyarakat harus terus digalakkan. Upaya ini perlu dilakukan sebagai salah satu upaya untuk menciptakan entrepreneur muda baru dan tangguh. Atas dasar hal tersebut maka dirancanglah program pengabdian kepada masyarakat dengan judul "Penumbuhan dan Pengembangan Wirausaha Baru pada Era Digital bagi Generasi Muda di Kecamatan Rumbai Kelurahan Agrowisata"

\section{Identifikasi Masalah}

Tingginya tingkat pengangguran Kota Pekanbaru disebabkan oleh banyak pemuda yang memilih mencari pekerjaan dari pada menciptakan lapangan pekerjaan. Padahal apabila dioptimalkan pengelolaan sumberdaya daerah yang ada bisa meningkatkan kesempatan kerja dan mengurangi pengangguran.

\section{Perumusan Masalah}

Bagaimana menumbuhkan dan mengembangkan wirausaha baru pada era digital bagi generasi muda di Kecamatan Rumbai Kelurahan Agro Wisata?

\section{Tujuan Kegiatan Pengabdian}

Tujuan yang ingin dicapai dari kegiatan ini adalah

a. Memberikan pengetahuan dasar tentang pentingnya spirit wirausaha, sehingga peserta mampu menjadi pengusaha yang maju, mandiri dan profesional.

b. Memberikan pengetahuan dasar tentang motivasi usaha dan strategi usaha dalam menghadapi persaingan pasar yang semakin ketat.

c. Memberikan pemahaman dan ketrampilan kepada peserta yang berkaitan dengan pengembangan bisnis, seperti bidang pemasaran, akuntansi, keuangan, permodalan, serta sumber daya manusia.
Kegiatan ini menumbuhkan dan mengembangkan wirausaha baru pada era digital bagi generasi muda ini mempunyai manfaat yaitu peserta mendapat motivasi lebih dalam dalam berwirausaha.

\section{Masyarakat Sasaran}

Dipilihnya pemuda di Kecamatan Rumbai Kelurahan Agrowisata ini sebagai masyarakat sasaran dengan pertimbangan bahwa para pemuda baik yang putus sekolah, tamat sekolah dan lulusan perguruan tinggi sekali pun masih belum punya motivasi dan pengetahuan berwirausaha, sehingga banyak yang memilih mencari kerja keluar sementara itu potensi daerah sangat besar.

\section{Tinjauan Pustaka \\ Motivasi}

Luthans (2005) memberikan definisi yang komprehensif, yakni motivation is a process that starts with a physiological or psychological deficiency or need that activates a behavior or a drive that is aimed at a goal or incentive, artinya motivasi merupakan suatu proses yang dimulai dengan suatu kekurangan fisiologis dan fisikologis atau kebutuhan yang menggerakkan suatu perilaku atau semangat terhadap suatu tujuan atau insentif.

Pentingnya motivasi selalu dihubungkan dengan tujuan pemberian motivasi itu sendiri. Secara umum tujuan pemberian motivasi adalah sebagai berikut: (1) Mendorong gairah dan semangat kerja; (2) Menciptakan suasana dan hubungan kerja yang baik; (3) Meningkatkan kepuasan kerja; (4) Meningkatkan kreatifitas, inovasi dan partisipasi kerja; (5) Meningkatkan efektifitas dan efisiensi kerja; (6) Meningkatkan produktivitas kerja; (7) Mempertahankan loyalitas; (8) Meningkatkan kedisplinan kerja; (9) Mempertinggi rasa tanggung jawab terhadap tugas dan fungsi; (10) Meningkatkan tingkat kesejahteraan; (11) Menanamkan rasa memiliki (sense of belonging) terhadap perusahaan; (12) Menciptakan rasa kebersamaan dan (13) Mendorong untuk berperilaku sebagai warga organisasi (organizational citizenship behavior). 
Training is a planned effort to facilitate the learning of jobrelated knowledge, skills, and behavior by employe. Pelatihan merupakan suatu usaha yang terencana untuk

memfasilitasi pembelajaran tentang pekerjaan yang berkaitan dengan pengetahuan, keahlian dan perilaku oleh pegawai. (Noe, Hollenbeck, Gerhart and Wright, 2003)

Secara ontologis, "training is a process used by organizations to meet their goals. It is called into operation when a discrepancy is perceived between the current situation and a preferred state of affairs. The trainer's role is to facilitate trainee's movement from the status qou toward the ideal. Pelatihan adalah upaya pembelajaran, yang diselenggarakan organisasi (instansi Pemerintah, lembaga swadaya masyarakat, perusahaan, dan lain sebagainya) untuk memenuhi kebutuhan atau untuk mencapai tujuan organisasi. Suatu pelatihan dianggap berhasil apabila dapat membawa kenyataan atau perfomansi sumber daya manusia yang seharusnya atau yang diinginkan oleh organisasi dan/atau lembaga. Peran pelatih (widyaiswara, instruktur, nara sumber) dalam proses pembelajaran adalah membantu (membelajarkan) peserta pelatihan untuk dapat mengubah perilaku yang biasa ditampilkan pada saat ini menjadi perilaku yang seharusnya terwujud atau yang diharapkan oleh organisasi dan/atau lembaga. (Friedman dan Yarbrough, 1985 dalam Sudjana, D., 2007). Dengan kata lain, pelatihan adalah kegiatan edukatif untuk membawa keadaan perilaku saat ini kepada perilaku yang lebih baik sebagaimana diinginkan oleh organisasi.

\section{Kewirausahaan/Entrepreneurship}

Entrepreneurship is the process of creating something different with vaule by devoting the necessary time and effort, assuming the accompanying financial, psyhic, and social risk, and receiving the resulting rewards of monetary and personal satisfaction and independence. Kewirausahaan adalah proses menciptakan sesuatu yang lain dengan menggunakan waktu dan kegiatan disertai modal dan resiko serta menerima balas jasa dan kepuasan serta kebebasan (HisrichPeters, 1995, dalam Alma, B. 2007)

Entrepreneurship is ability to create the new and different thing. Kewirausahaan adalah suatu kemampuan untuk menciptakan sesuatu yang baru dan berbeda. Kewirausahaan secara sederhana sering juga diartikan sebagai prinsip atau kemampuan wirausaha (Drucker, P.F, 1994). Entrepreneurship is the backbone of economy. Kewiraushaaan syaraf pusat perekonomian atau sebagai ,tailbone of economy", yaitu pengendali perekonomian suatu bangsa (Wirakusumo, S. 1997, dalam Suryana, 2007).

\section{Pemberdayaan}

Secara empiris, ada tiga konsep pemberdayaan itu ; 1) pemberdayaan itu sebagai penghancuran kekuasaan (power to no body). Kekuasaan yang ada diupayakan untuk dihancurkan dan diganti. Karena semakin lama berkuasa dalam menjalankan kekuasaannya cenderung untuk mengharamkan segala cara (otoriter). Tetapi konsep ini sangat revolusioner dan kurang demokratis; 2) pemberdayaan diartikan sebagai pembagian kekuasaan kepada setiap orang (power to every body); dengan adanya pembagian kekuasaan, maka kemungkinan untuk menyalahgunakan kekuasaan semakin kurang karena dikontrol oleh pihak yang lain; dan 3) pemberdayaan diartikan sebagai penguatan yang lemah tanpa menghancurkan yang kuat. Konsep ini merupakan konsep yang memiliki semangat demokratis di mana semua komponen masyarakat dihargai apa adanya; yang lemah dikuatkan sedangkan yang kuat dijaga untuk membantu yang lemah sehingga semua akan menjadi sama-sama (A. Rasyad, 2014). Kata power dalam empowerment diartikan "daya" sehingga empowerment diartikan sebagai pemberdayaan. Pemberdayaan adalah penguatan masyarakat untuk dapat berpartisipasi dalam proses pengambilan keputusan yang mempengaruhi masa depannya, penguatan masyarakat untuk menentukan pilihan masa depannya.

\section{Metodologi Penelitian}




\section{Langkah - Langkah Kegiatan \\ Tahap Persiapan}

Tahap persiapan merupakan tahap yang diperlukan untuk mengumpulkan informasi yang berkaitan dengan kelompok sasaran. Tahap persiapan ini terdiri dari :

a. Mengumpulkan data calon peserta yakni pemuda Kecamatan Rumbai Kelurahan Agrowisata Kota Pekanbaru.

b. Diskusi dengan anggota pelaksana dan penentuan beban kerja anggota tim.

c. Mempersiapkan peralatan serta bahan yang diperlukan.

\section{Tahap Pelaksanaan Kegiatan}

Adapun tahapan pelaksanaan kegiatan sebagai berikut : (1) Temu Ramah Bersama Masyarakat Kelurahan Agrowisata; (2) Sosialisasi Kukerta Terintegrasi Bersama Camat Rumbai dan Lurah Agrowisata, serta Penyerahan Resmi; (3) Agenda Kegiatan Inti Sosialisasi Kewirausahaan Berbasis Era Digital; (4) Lokakarya Tim Pengabdian Masyarakat

\section{Tahap-tahap Pengembangan Kewirausahaan Pemuda}

Pengembangan kewirausahaan pemuda mencakup tahapan-tahapan sebagai berikut :

1. Tahap Akan Memulai Usaha (Pre start-up stage)

2. Tahap Memulai Usaha (The start-up stage)

3. Tahap Pertumbuhan Awal (Early-growth stage)

4. Tahap Pertumbuhan Lanjutan (Later-growth stage)

\section{Waktu dan Tempat}

Kegiatan penumbuhan dan pengembangan wirausaha baru pada era digital bagi generasi muda Kecamatan Rumbai Kelurahan Agrowisata Kota Pekanbaru diadakan di aula Kantor Camat dilakukan pada hari Minggu tanggal 14 Juli 2019.

\section{Peserta}

Peserta kegiatan sebanyak 40 (Empat Puluh) Pemuda yang terdapat di Kecamatan Rumbai Kelurahan Agrowisata Kota Pekanbaru

\section{Hasil dan Pembahasan}

\section{Gambaran Umum Masyarakat Sasaran}

Kelurahan Agrowisata merupakan kelurahan yang terdapat di Kecamatan Rumbai Kota Pekanbaru. Kelurahan Agrowisata merupakan pemerkaran dari Kelurahan Palas Kecamatan Rumbai Pesisir. Awal tahun 2016, masyarakat sudah dijuluki Kelurahan Agrowisata. Penyebutan ini berawal dari warga setempat yang gemar menanam beragam sayur, buah dan berternak. Kelurahan ini dicanangkan oleh pemerintah sebagai pusat agrowisata di Kota Pekanbaru. Pada akhir tahun 2018 yang lalu Pemerintah Kota Pekanbaru meresmikan agrotek farm system, sistem ini nantinya petani akan lebih dimudahakan dalam melakukan aktifitas pertanian karena sejumlah aktivitas dapat dikerjakan melalui sistem android. Inovasi ini berjutuan mengatur pengairan, mengatur pupuk dengan sistem Andoid, petani dalam beberapa meter dan waktu yang ditentukan dapat menyiram tanaman yang sudah terkoneksi ke Android.

Sebelum melakukan pengabdian kepada masyarakat tim pengabdian LPPM Universitas Riau melakukan terlebih dahulu pemetaan mengenai gambaran umum masyarakat sasaran. Dibawah ini merupakan responden berdasarkan jenis pekerjaan didominasi oleh wirausaha dan wiraswasta di Kelurahan Agrowisata sebagai berikut:

\section{Gambar 1}

\section{Responden Berdasarkan Jenis Pekerjaan}


FE Universitas Maritim Raja Ali Haji

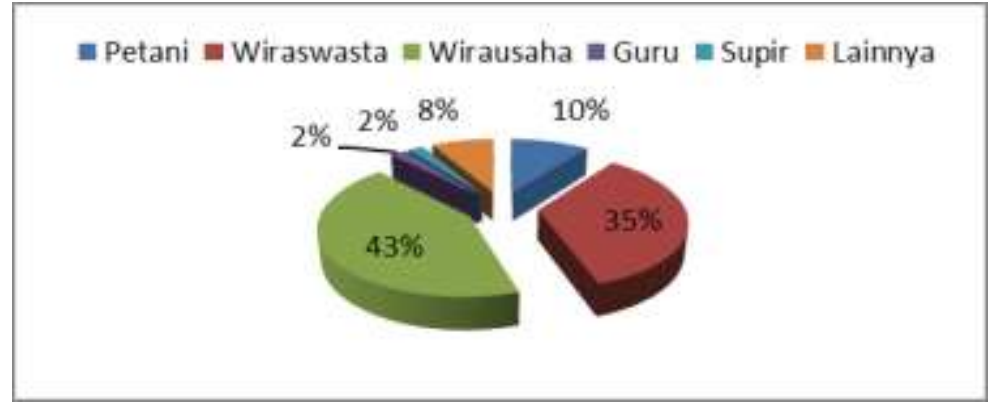

Sumber: Hasil Survei

Hasil survei menunjukkan responden berdasarkan jenis pekerjaan didominasi oleh wirausaha sebesar $43 \%$, wiraswasta sebesar $35 \%$, petani sebesar
$10 \%$, guru dan supir sebesar $2 \%$, dan jenis pekerjaan lainnya sebesar $8 \%$.

Grafik 2

Responden Berdasarkan Umur Responden

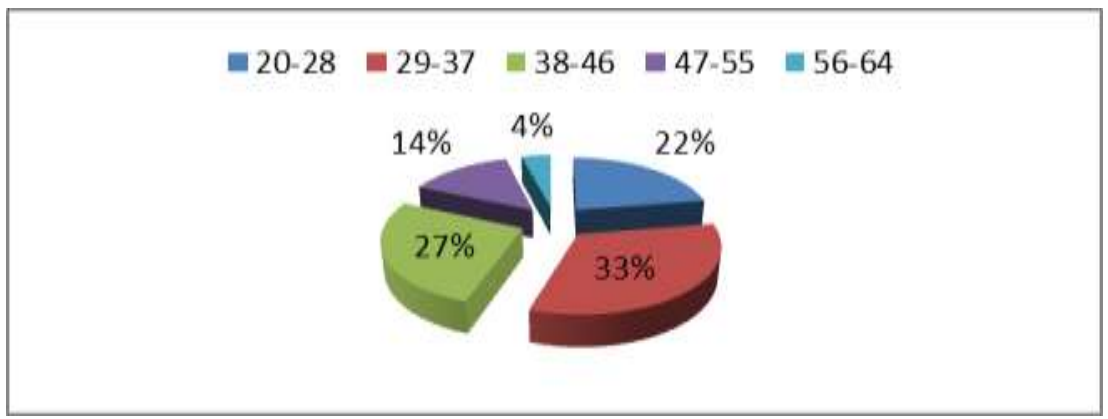

Sumber: Hasil Survei

Hasil survei lapangan menunjukkan umur responden didominasi oleh responden usia 29-37 tahun sebesar 33\%, umur 38-46 tahun sebesar $27 \%$, umur 20-28 tahun sebesar 22\%, umur 47-55 tahun sebesar $14 \%$ dan umur responden $56-64$ tahun sebesar $4 \%$.
Berikut disampaikan data responden berdasarkan tingkat pengeluaran di Kelurahan Agrowisata didominasi oleh responden dengan tingkat pengeluaran Rp. 1.000.000-Rp.2.000.000 sebagai berikut:

\section{Grafik 3}

\section{Responden Berdasarkan Tingkat Pengeluaran}

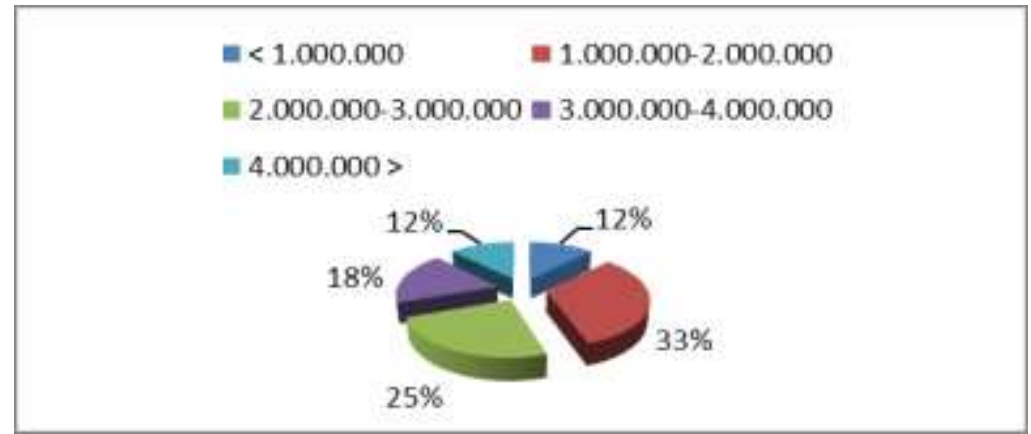

Sumber: Hasil Survei 
Hasil survei lapangan menunjukkan tingkat pengeluaran responden Kelurahan Agrowisata didomonasi oleh responden dengan tingjkat pengeluaran Rp. 1.000.000-Rp.2.000.000 sebesar $33 \%$, responden dengan tingkat pengeluaran $\mathrm{Rp}$. 2.000.000-Rp. 3.000.000 sebesar 25\%, responden dengan tingkat pengeluaran Rp. 3.000.000-
Rp.4.000.000 sebesar 18\%, responden dengan tingkat pengeluaran Rp. 1.000.000 kebawah dan Rp. 4.000.000 keatas sebesar $12 \%$.

Responden berdasarkan kepemilikan usaha didominasi oleh responden yang memiliki usaha yaitu sebagai berikut:

\section{Grafik 4}

\section{Responden Menurut Kepemilikan Usaha}

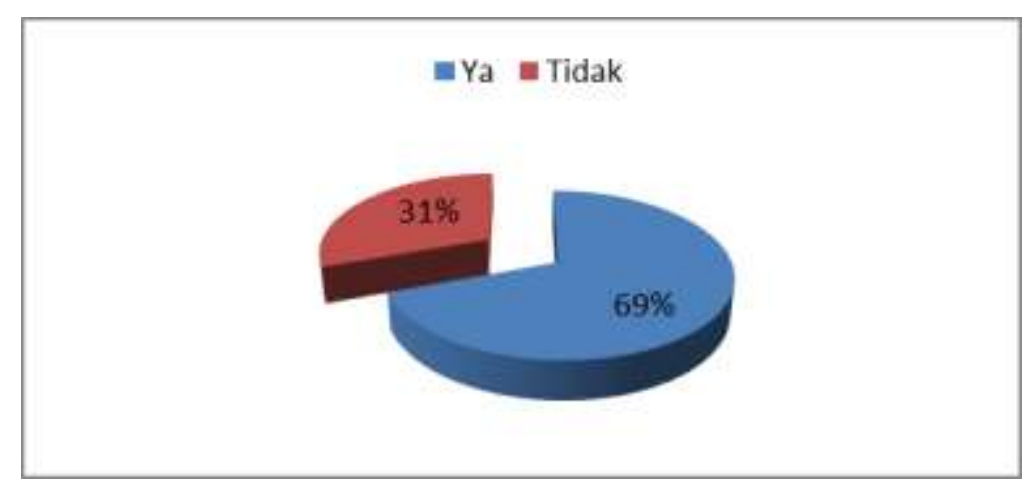

Sumber: Hasil Survei

Hasil survei lapangan menunjukkan responden menurut kepemilikan usaha didominasi oleh responden yang memiliki usaha sebanyak $69 \%$ dan yang tidak memiliki usaha sebanyak $31 \%$. Respon yang tidak memiliki usaha merupakan responden yang berpropesi sebagai karyawan.
Berikut disajikan data karakteristik responden berdasdarkan kendala dalam pengelolaan usaha didominasi oleh responden dengan kendala modal yaitu sebagai berikut:

\section{Grafik 5}

\section{Responden Berdasarkan Kendala Pengelolaan Usaha}

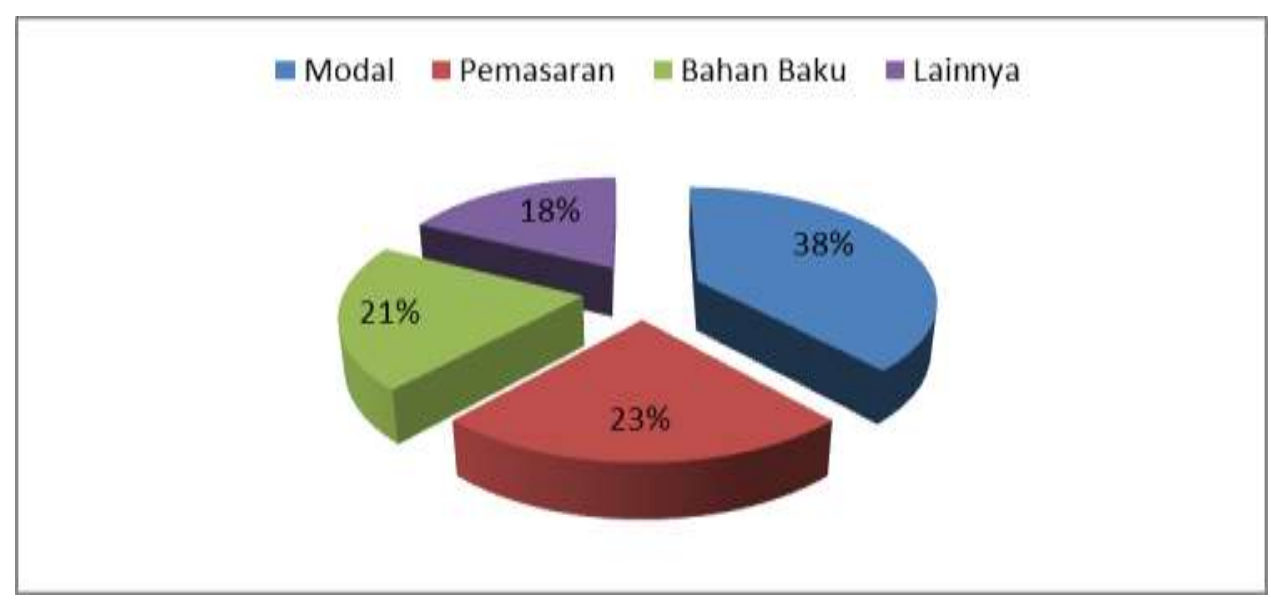

Sumber: Hasil Survei 
Data hasil survei lapangan menunjukkan responden dengan kendala pengelolaan usaha didominasi oleh kendala modal sebesar 38\%, kendala pemasaran sebesar 23\%, kendala bahan baku sebesar $21 \%$ dan kendala lainnya sebesar $18 \%$. Besarnya kendala modal disebabkan oleh usaha masyarakat Kelurahan Agrowisata berbasis produksi sehingga membutuhkan modal yang cukup besar.

Berikut disampaikan data responden berdasarkan usaha yang sejalan dengan potensi desa yaitu sebagai berikut:

\section{Grafik 6}

Usaha Responden yang Sejalan dengan Potensi Desa

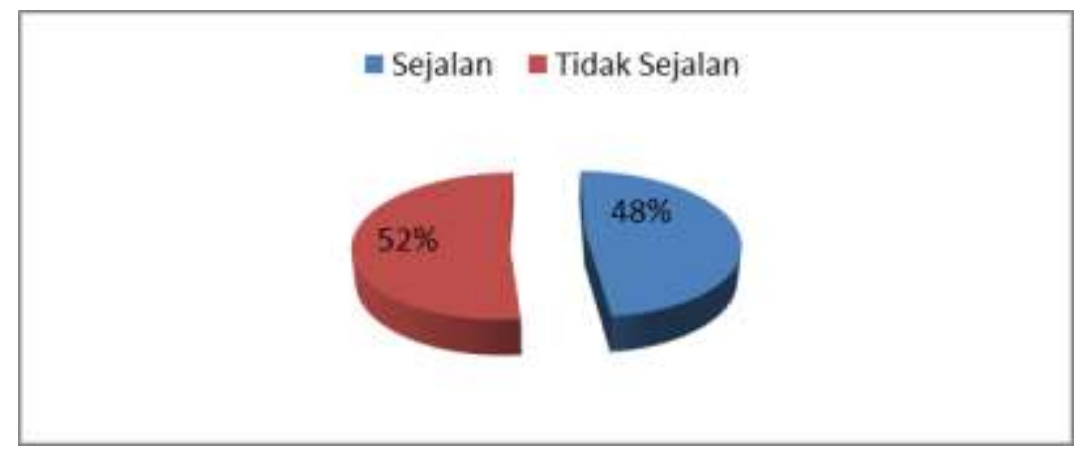

Sumber: Hasil Survei

Data hasil survei menunjukkan sebagian besar usaha responden yang tidak sejalan dengan potensi desa sebanyak $52 \%$ dan $48 \%$ nya sejalan dengan potensi desa. Besarnya usaha yang tidak sejalan dengan potensi desa disebabkan oleh usaha masyarakat menggeluti bidang perdagangan dan jasa.
Berikut disampaikan data responden yang menggunakan sosial media dalam pengembangan usaha didominasi oleh responden yang tidak menggunakan sosial media yaitu sebagai berikut:

Grafik 7

Menggunakan Sosial Media dalam Pengembangan Usaha

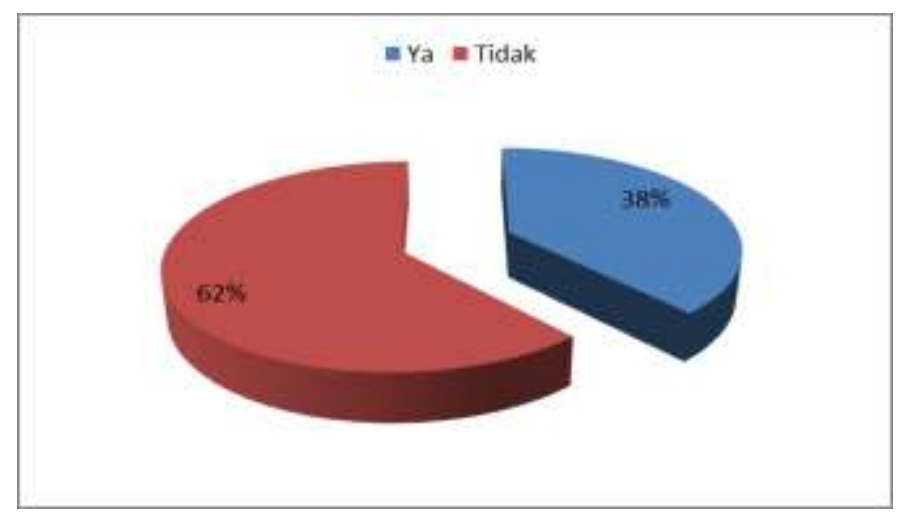

Sumber: Hasil Survei

Hasil survei lapangan menunjukkan responden yang menggunakan sosial media dalam pengembangan usaha didominasi oleh responden yang tidak menggunakan sosial media yaitu sebanyak $62 \%$ dan $38 \%$ nya lagi menggunakan sosial media. Penyebabnya terdapat pada gambar diatas yaitu sebagai berikut: 


\title{
Grafik 8
}

Alasan Tidak Menggunakan Sosial Media

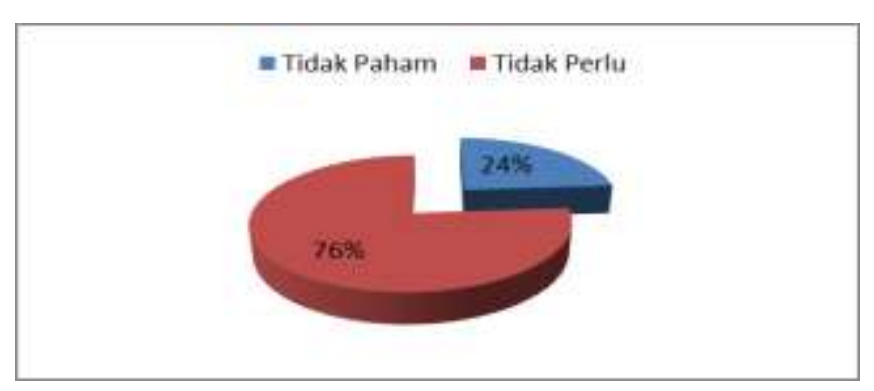

Sumber: Hasil Survei

\begin{abstract}
Alasan responden tidak menggunakan sosial usahanya tidak terkait dengan penggunaan sosial media untuk pengembangan usaha adalah media. Sebanyak $24 \%$ nya lagi responden tidak sebagian besar responden merasa tidak perlu dan paham menggunakan sosial media.
\end{abstract}

\section{Grafik 9}

Pengearuh Omset Setelah Menggunakan Sosial Media

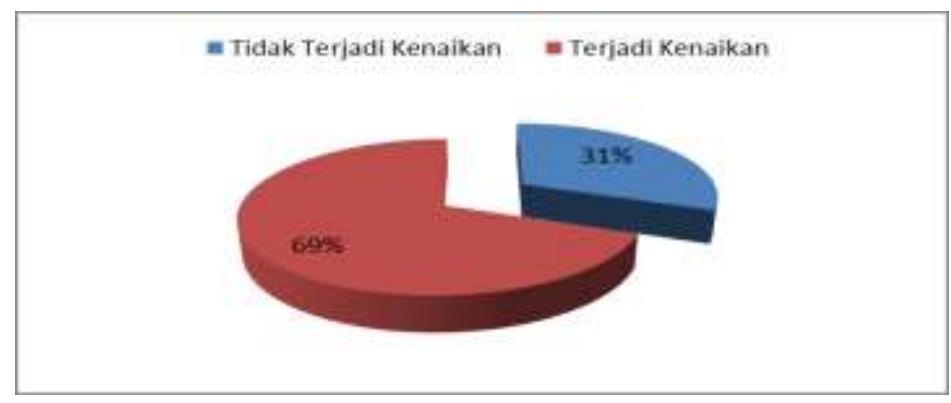

Sumber: Hasil Survei

Responden yang menggunakan sosial media untuk pengembangan usahanya hanya sebanyak $31 \%$ yang merasakan terjadi kenaikan omset sementara 69\% nya lagi tidak merasakan pengaruh apapun setelah menggunakan sosial media.
Berikut disampaikan data responden yang mengikuti kegiatan enterpreneurship yaitu sebagai berikut:

Grafik 10

Responden yang Mengikuti Pelatihan 


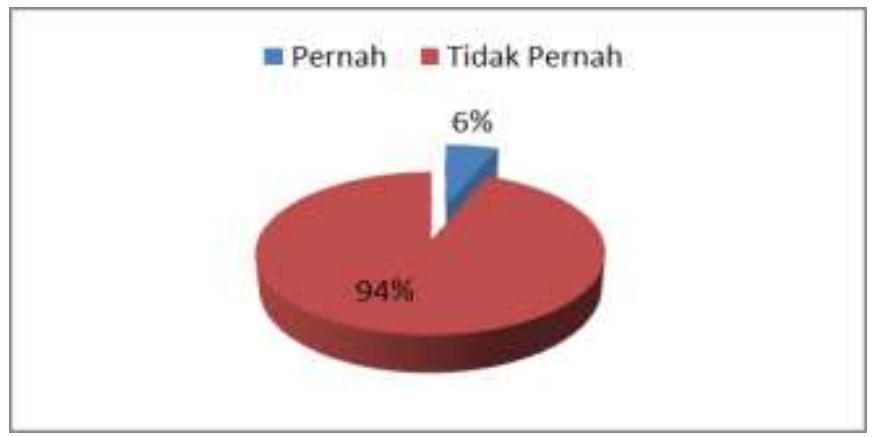

Sumber: Hasil Survei

Hasil survei lapangan menunjukkan responden di Kelurahan Agrowisata sebagian besar tidak pernah mengikuti pelatihan yaitu sebesar $94 \%$ dan yang pernah mengikuti pelatihan hanya $6 \%$ nya saja.

\section{Grafik 11}

Materi Yang Dibutuhkan Jika Mengikuti Pelatihan

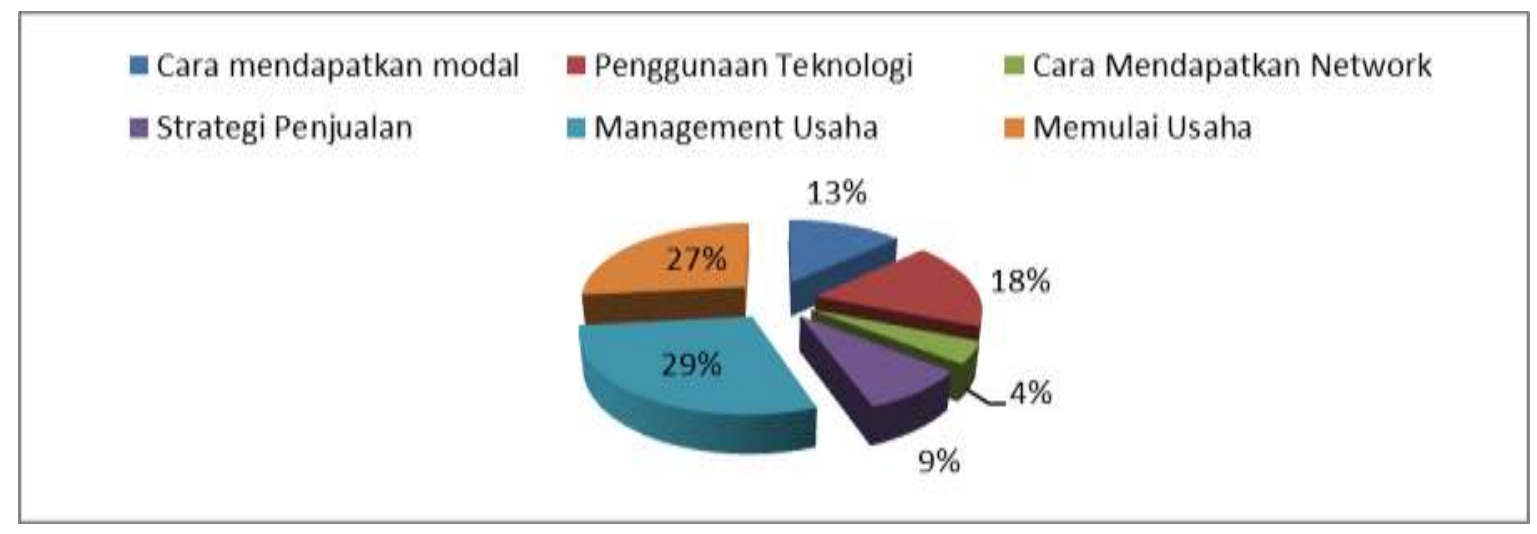

Sumber: Hasil Survei

Adapun materi yang dibutuhkan oleh responden jika mengikuti kegiatan pelatihan enterpreneurship didominasi oleh materi yang berkaitan dengan management usaha sebesar 29\%, materi cara memulai usaha sebesar $27 \%$, materi penggunaan teknologi sebesar $18 \%$, materi cara mendapatkan modal usaha sebesar $13 \%$, materi tentang strategi penjualan sebesar $9 \%$ dan materi cara mendapatkan network sebesar $4 \%$.

\section{Potensi Pengembangan (Pemberdayaan Masyarakat)}

Pengabdian ini diberikan kepada pemuda, gapoktan dan elemen masyarakat yang ada di Kelurahan Agrowisata Kecamatan Rumbai. Sesuai namanya yaitu kelurahan agrowisata, merupakan kelurahan yang sedang dicanangkan Pemerintah Kota untuk menjadi pusat agrowisata di Kota Pekanbaru.

Potensi yang dimiliki Kelurahan Agrowisata diantaranya adalah 100 hektar lahan pertanian yang sudah disiapkan sebagai penunjang wisata agro oleh pemerintah. Selain itu luasnya lahan melon masyarakat juga merupakan potensi yang sangat bagus untuk dikembangkan selain menjadi tempat agrowisata juga bisa dikembangkan menjadi indutri turunan lainnya baik itu industri makanan maupun kesehatan.

Selain itu terdapat luasnya lahan pertanian ubi masyarakat dengan potensi yang sangat luar biasa yaitu dalam 1 batang ubi bisa menghasilkan $200 \mathrm{Kg}$ buah ubi. Sehingga melimpahnya bahan baku kalau dikelola dengan baik akan mampu 
memberikan multiplier effect kepada perekonomian masyarakat di Kelurahan Agrowisata dan Kelurahan sekitar.

Melalui potensi yang ada jika benar-benar serius untuk dikembangkan selain menjadi tempat wisata alternatif kota pekanbaru juga mampu mensupply bahan baku untuk kebutuhan indutri kecil, menengah maupun besar.

\section{Solusi Pengembangan (Pemberdayaan) Masyarakat}

Langkah yang dilakukan agar masyarakat mampu mengembangkan potensi desa adalah tim pengebdian melakukan kegiatan enterpreneurship berdasarkan kebutuhan masyarakat Kelurahan Agrowisata melalui pemetaan kondisi masyarakat menggunakan kusioner. Materi pertama yang diberikan oleh tim kepada masyarat adalah materi yang berkaitan dengan modal, tujuan meteri ini diberikan agar masyarakat menjadi mudah mendapatkan akses untuk modal usaha melalui dana CSR perusahaan, pinjaman dengan bunga yang kecil maupun akses dana ke Perbankan.

Adapun materi kedua berkaitan dengan manegement pengelolaan usaha dan pembukuan. Tujuan materi ini diberikan kepada masyarakat adalah agar masyarakat paham bagaimana management pengelolaan usaha yang bagus dan juga pembukuan yang bagus. Baiknya pembukuan suatu usaha akan berguna jika melakukan pengajuan pinjaman dana.

Materi ketiga berkaitan dengan digital marketing. Tujuan materi ini diberikan kepada adalah supaya masyarakat paham bagai mana mengoptimalkan potensi internet untuk aspek pemasaran, selain mampu menjangkau pembeli potensial yang tidak terbatas juga mampu menghemat cost iklan.

\section{Tingkat Ketercapaian Sasaran Program}

Geliat enterpreneurship dikalangan masyarakat khususnya anak muda terus mengalami peningkatan signifikan. Enterpreneurship memiliki peranan penting dengan kemampuan untuk menciptakan dan menyediakan produk yang bernilai tambah (value added) melalui keberanian mengambil resiko, kreativitas dan inovasi serta kemampuan manajemen untuk mencari dan membaca peluang. Semakin banyak Entrepreneur yang dimiliki oleh sebuah negara akan semakin makmur negara tersebut. Menciptakan sebanyak mungkin Entrepreneur di suatu negara jelas memiliki kaitan dengan kesejahteraan bangsa tersebut.

Jika diprediksi maka tingkat keberhasilan dari program yang dijalankan ini diperkirakan diatas $80 \%$ akan berhasil. Prediksi ini tentunya akan dapat di wujudkan jika peran serta pemerintah, swasta, masyarakat dan perguruan tinggi saling bersinergis dalam mendorong munculnya enterpreneur baru melalui pelatihan, pendampingan, transfer teknologi dan permudah perizinan akan mempercepat lahirnya enterpreneur baru. Terlebih lagi pesatnya perkembangan teknologi akan sangat mempermudah siapapun, kapanpun dan dimana pun untuk memulai usaha. Untuk itu tim pengabdian sangat optimis capaian sasaran program akan optimal seperti yang diharapkan oleh banyak pihak.

\section{Kesimpulan}

\section{Kesimpulan}

1. Masih banyaknya masyarakat Kelurahan Agrowisata yang belum paham dalam mengelola usaha.

2. Sebagian besar usaha masyarakat tidak terkait dengan potensi daerah.

3. Masih kurangnya generasi muda Kelurahan Agrowisata dalam memulai usaha.

4. Hanya $6 \%$ masyarakat yang pernah mengikuti pelatihan enterpreneurship

5. Sebagian besar masyarak belum menyadari kemampuan sosial media dalam mendorong kemajuan usaha.

\section{Saran}

1. Pihak kelurahan bekerja sama dengan Pemerintah Kota Pekanbaru melalui OPD terkait untuk melakukan pelatihan enterpreneurship secara 
rutin guna mendorong masyarakat agar tertarik dengan dunia usaha.

2. Menggandeng perguruan tinggi dan swasta untuk transfer teknologi

3. Bekerjasama dengan lembaga keuangan bank maupun non bank untuk akses pembiayaan usaha masyarakat.

4. Bekerjasama dengan Perusahaan yang mempunyai CSR dalam melakukan pemberdayaan kepada usaha masyarakat.

\section{Daftar Pustaka}

Alma, B. (2007). Kewirausahaan. Bandung: Alfabeta.

Drucker, P.F. (1994). Innovation and Entrepreneurship, Practice and Principle. New York. Harper Business.

Dewi, Erwitas et al (2012). Pelatihan Motivasi Kewirausahaan Bagi Tim Penggerak PKK Kelurahan Rawasari Kecamatan Kota Baru Jambi. Jurnal Pengabdian pada Masyarakat No. 52.

Hikmat, H. (2010). Strategi Pemberdayaan Masyarakat. Bandung: Humaniora Utama Press.

Kamil, M. (2010). Model Pendidikan dan Pelatihan (Konsep dan Aplikasi), Bandung: Alfabeta.

Marzuki, S. (2010). Pendidikan Nonformal; Dimensi dalam Keaksaraan Fungsioal. Pelatihan, dan Andragogi. Malang: UM Press Kerjasama dengan Bandung: Rosdakarya.

Noe, Hollenbeck, Gerhart, Wright (2003). Human Resource Management, International Edition. New York: The McGraw-hill Companies Inc..

Rasyad, A. 2014. Pendidikan dan Pelatihan dalam Pemberdayaan Masyarakat. Malang: Elang Mas.
Sudjana, D. (2007) Sistem dan Manajemen Pelatihan, Teori dan Aplikasi. Bandung: Falah Production.

Winarto, (2004). First Step to Be An Entrepreneur. Jakarta. Elex Media Komputindo.

Zimmerer, T.W., \& Norman M. S. (1996). Entrepreneurship And The New Venture Formation. New Jersey. Prentice-Hall International, Inc. 